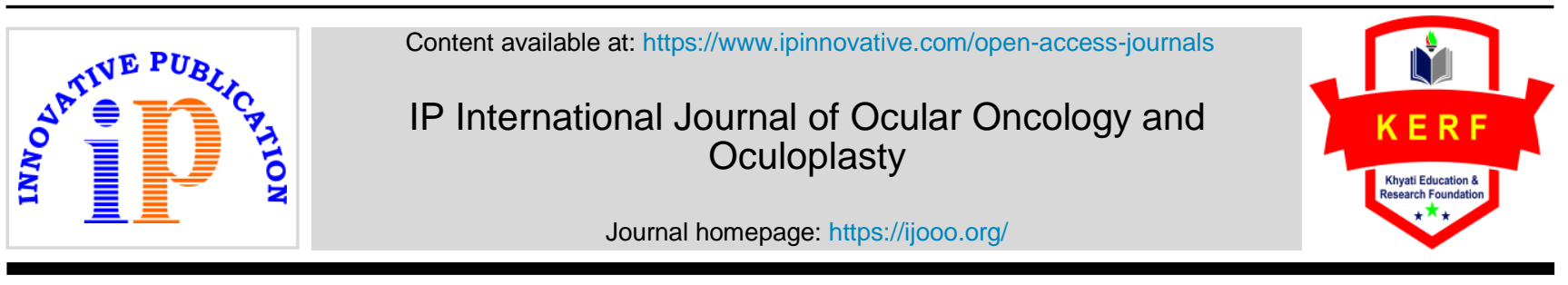

\title{
Editorial
}

\section{Paraneoplastic orbital syndrome: A rare entity}

\author{
Rajendra P Maurya ${ }^{1}$ ** \\ ${ }^{1}$ Regional Institute of Ophthalmology, Institute of Medical Sciences, Banaras Hindu University, Varanasi, Uttar Pradesh, India
}

\section{A R T I C L E I N F O}

Article history:

Received 20-03-2021

Accepted 31-03-2021

Available online 28-04-2021
(C) This is an open access article distributed under the terms of the Creative Commons Attribution License (https://creativecommons.org/licenses/by/4.0/) which permits unrestricted use, distribution, and reproduction in any medium, provided the original author and source are credited.
Paraneoplastic orbital syndromes involving eye and orbit are rare entities. Ocular paraneoplastic syndromes (OPS) are heterogenous group of disorders due to remote effects of systemic malignancy not related to the size of tumor or direct tumor invasion or its metastasis. ${ }^{1,2}$ It can occur before diagnosis of cancer and even after tumor has been excised. Sometimes it can be the initial presenting symptom of the disease. The systemic malignancies most commonly associated with paraneoplastic syndromes (PNS) are lung cancer, breast cancer, ovarian cancer, renal carcinoma and leukemias etc. ${ }^{2}$

The first ocular paraneoplastic syndrome was reported by Sawyer et al in $1976^{1}$. The different types of OPS are paraneoplastic retinopathy, paraneoplastic optic neuropathy and paraneoplastic orbital syndromes. The mechanism of paraneoplastic syndrome is unknown. It has been reported that paraneoplastic syndromes are immune mediated, caused by autoimmune reaction triggered by malignant tumor and directed against antigens common to both cancer cells and neuromuscular tissue or nervous system. ${ }^{3}$ The PNS are associated with elevated levels of paraneoplastic antibodies (onco-neuronal antibodies) against the above mentioned antigens. ${ }^{4}$ The onco-neuronal antibodies can also be used as diagnostic biomarkers for diagnosis of PNS. ${ }^{5}$

Paraneoplastic orbital syndrome consists of extraocular muscle palsy and ptosis. without any muscle infiltration

\footnotetext{
* Corresponding author.

E-mail address: mauryarp_bhu@yahoo.com (R. P. Maurya).
}

or mass effects mainly due to neuromuscular disorders associated with aggressive cellular or humoral response against the tumor. ${ }^{6}$ It has been described that patients of small cell lung cancer develop paraneoplastic antibody which blocks the neuromuscular transmission resulting in a myasthenic like syndrome, which is known as LambertEaton myasthenic syndrome. ${ }^{7}$

Paraneoplastic retinopathies includes cancer associated retinopathy (CAR) and melanoma -associated retinopathy (MAR). CAR is always associated with small cell lung cancer (SCLC) and is characterized by bilateral simultaneous dysfunction of both cones and rods. Patients may present with photosensitivity, decreased visual acuity and color perception, nyctalopia, prolonged dark adaptation and in electroretinogram there may be flattening or severe attenuation of both photopic and scotopic response.

CAR is mainly caused by p53 gene mutation in tumor cells which leads to over expression of highly immunogenic "recoverin protein" and body immune system produces high levels of paraneoplastic antibody (antirecoverin $\operatorname{IgG}$ ). Recoverin specific T-cell mediated reactions cause photoreceptor cell death, ${ }^{1,8}$

Melanoma associated retinopathy (MAR) usually occur in patients of malignant melanoma, where paraneoplastic retinopathy leads to pure dysfunction of rods without any involvement of cone. Patients usually have normal visual acuity and color vision and symptoms are mainly night blindness and mild peripheral visual field loss. ${ }^{1,9}$ 
Diagnosis of PNS is quite difficult as majority of patients with PNS get diagnosis of malignancy by several months to years. Detection of onconeuronal antibody in suspected patients of PNS is the most valuable test but unfortunately, about $50 \%$ of individuals with PNS do not have any specific onconeuronal antibodies. ${ }^{5}$ Identification of tumor is essential but may be difficult, if antibodies are present then direct search of specific tumor through CT Scan or whole body positron emission tomography (PET) is helpful.

Immunomodulatory treatment for PNS is usually ineffective because in most of the cases symptoms are due to irreversible destruction of neural or myoneural structures. However it has been reported that intravenous immunoglobulins, steroids or plasmapheresis may improve in some cases. ${ }^{10,11}$

\section{Conflicts of interest}

None.

\section{References}

1. Kordys M, Dolyk JP, Krecicka AT, Misiuk-Hoto M. Immunopathogenesis of ophthalmological paraneoplastic syndromes: Recent findings. Adv Clin Exp Med. 2018;27(10):1431-

2. Muir C. Cancer of unknown primary site. Cancer. 1995;75:353-6.

3. Darnell RB, Posner JB. Paraneoplastic Syndromes Involving the Nervous System. $N$ Eng J Med . 2003;349(16):1543-54. doi:10.1056/nejmra023009.

4. Vianello M, Vitaliani R, Pezzani R, Nicolao P, Betterle C, Keir $\mathrm{G}$, et al. The spectrum of antineuronal autoantibodies in a series of neurological patients. J Neurol Soc . 2004;220(1-2):29-36. doi:10.1016/j.jns.2004.01.008.

5. Graus F, Delattre JY, Antoine JC, Dalmau J, Giometto B, Grisold $\mathrm{W}$, et al. Recommended diagnostic criteria for paraneoplastic neurological syndromes. J Neurol Neurosurg Psychitry.
2004;75:1135-40.

6. Spraul CW, Lang GE, Lang GK. Orbital myopathy in metastatic malignant paraganglioma: a paraneoplastic syndrome ? Klin Monbl Augenheilkd. 1996;209:153-7.

7. Rojas-Marcos I, Rene R, Graus F. Paraneoplastic syndromes in otoneuro-ophthalmology. Rev Neurol.2000;31:1206-12.

8. Machida S, Ohguro H, Ishida K, Suzuki M, Kawagishi K. Recoverin- associated retinopathy secondary to Warthin tumor of parotid gland. Doc Ophthalmol . 2014;129(2):123-8. doi:10.1007/s10633-014- 9456-8.

9. Morita Y, Kimura K, Fujitsu Y. Autoantibodies to transient receptor potential cation channel, subfamily $\mathrm{M}$, member 1 in a Japanese patient with melanoma-associated retinopathy. Jpn J Ophthalmol. 2014;58(2):166-72.

10. Vernino S, O'Neill BP, Marks RS, O'Fallon JR, Kimmel DW. Immunomodulatory treatment trial for paraneoplastic neurologicaldisorders. Neuro-Oncol. 2004;6(1):55-62. doi:10.1215/s1152851703000395.

11. Widdess-Walsh P, Tavee JO, Schuele S, Stevens GH. Response to intravenous immunoglobulin in anti-Yo associated paraneoplastic cerebellar degeneration: case report and review of the literature. J Neuroncol. 2003;63:187-90.

\section{Author biography}

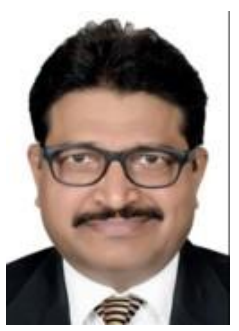

Rajendra P Maurya, (MS, Ph.D) Editor in Chief IP IJOOO, Associate Professor \& In-charge Orbit, Ocular Oncology and Oculoplasty Unit Regional Institute of Ophthalmology, Institute of Medical Sciences, Banaras Hindu University, Varanasi, Uttar Pradesh, India.

E-mail: editorijceo@gmail.com, mauryarp_bhu@yahoo.com

Cite this article: Maurya RP. Paraneoplastic Orbital Syndrome: A Rare Entity. IP Int J Ocul Oncol Oculoplasty 2021;7(1):1-2. 